\title{
Растительность лесостепной зоны Северного Казахстана, классификация и антропогенная трансформация
}

\section{Vegetation of forest-steppe zone in Northern Kazakhstan, classification and anthropogenic transformation}

\author{
Пермитина В. Н. ${ }^{1}$, Байбулов А. Б. ${ }^{2}$ \\ Permitina V. N. ${ }^{1}$, Baibulov A. B. ${ }^{2}$ \\ ${ }^{1}$ Институт ботаники и фитоинтродукиии КН МОН РК, г. Алматы, Казахстан. E-mail: v.permitina@mail.ru, \\ ${ }^{2}$ ТОО Центр дистанционного зондирования и ГИС «Терра», г. Алматы, Казахстан. E-mail: baibulov@gis-terra.kz \\ ${ }^{I}$ Institute of Botany and Phytointroduction Science committee-Ministry of Education and Science of the RK, Almaty, Kazakhstan \\ ${ }^{2}$ Centre for Remote Sensing and GIS "Terra", Almaty, Kazakhstan
}

Peфepam. Изложены результаты исследований растительности лесостепной зоны Северного Казахстана. Выделено четыре типа растительности: степной, луговой, болотный, лесной. Приведена характеристика растительности в соответствии с закономерностями пространственного распределения сообществ, обусловленными рельефом местности, условиями увлажнения и типом почв. Отмечены наиболее распространенные растительные сообщества, показан флористический состав сообществ с выделением доминирующих и содоминирующих видов. Рассмотрены антропогенно преобразованные сорные производные сообщества залежных земель разных стадий восстановления.

Ключевые слова. Антропогенная трансформация, лесостепь, тип растительности, Северный Казахстан, флористический состав.

Summary. The results of studies of vegetation in the forest-steppe zone of northern Kazakhstan are presented. Four types of vegetation have been identified: steppe, meadow, marsh, and forest. The traits of vegetation in accordance with the regularities of the spatial distribution of communities, due to the terrain, conditions of moisture and the type of soil are showed. The most common plant communities are noted, the floristic composition of communities is shown with the selection of dominant and co-dominant species. The anthropogenically transformed derivatives communities of weed on fallow lands presented by different stages of restoration are considered.

Key words. Anthropogenic transformation, forest-steppe, vegetation type, Northern Kazakhstan, floristic composition.

Территория обследования принадлежит Евразиатской степной области, Причерноморско-Казахстанской подобласти, Западносибирской лесостепной провинции, лесостепному высотному поясу с распространением луговых степей и остепненных лугов (Природное районирование..., 1960; Природные условия..., 1969; Лавренко и др., 1991). Поверхность представляет денудационную волнистую равнину с чередованием плоских или слабо всхолмленных поверхностей с небольшими понижениями, бессточными впадинами, занятыми озерами и мелкими западинами, сложенную третичными и четвертичными желто-бурыми суглинками. Абсолютные высоты составляют 200-300 м.

Наибольшим распространением пользуется подтип черноземов обыкновенных среднегумусных, развивающийся в условиях сравнительно небольшого количества осадков по повышенным участкам волнистых равнин вне влияния грунтовых вод. Разнообразные условия почвообразования района с близко залегающими грунтовыми водами способствуют образованию почв лугового ряда и различной степени засоления. По широким пониженным равнинам или плоским понижениям встречаются лугово-черноземные почвы, в замкнутых и глубоких западинах, по террасам озер развиваются луговые почвы. Неглубокое залегание соленосных глин и минерализованных грунтовых вод обусловливает об- 
разование почв различной степени солонцеватости и солончаковатости, формирование солонцов и солончаков. Солонцы встречаются также в виде пятен по понижениям микрорельефа среди зональных почв. Под лесами и колками развиваются серые лесные почвы и солоди (Пачикина, Рубинштейн, 1960; Федорин, 1960).

Растительность лесостепи представлена сочетаниями лесных участков с разнотравно-ковыльными степями. В пределах исследованной территории выделено четыре типа растительности: степной, луговой, болотный и лесной, в которых объединены сообщества с доминантами, принадлежащими одной экобиоморфе и экологически сходными группами видов. К степному типу растительности отнесены сообщества с преобладанием ксерофитных дерновинных злаков при значительном участии разнотравья. Луговой тип растительности включает сообщества, образованные мезофитным разнотравьем и злаками. Луга подразделены на остепненные, настоящие, болотистые и галофитные. Луговая растительность включает сообщества, состоящие из мезофитов, занимает местообитания с дополнительным грунтовым и атмосферным увлажнением - берега озер, западины и пр. К травяным болотам отнесены сообщества, формирующиеся в условиях избыточного увлажнения на почвах болотного ряда, в сообществах преобладают крупные корневищные злаки, осоки и разнотравье. Лесная растительность развивается в депрессиях рельефа на солодях лесных, образована мелколиственными древесными породами с кустарниковым и травяным ярусом.

\section{Злаковые и разнотравно-злаковые степи}

Степной тип растительности представлен настоящими и луговыми степями на почвах автоморфного ряда увлажнения - черноземах обыкновенных среднегумусных, занимающих волнистые равнинные пространства. Для растительного покрова характерно доминирование дерновинных злаков - перистые ковыли (Stipa zalesskii Wilensky), ковыль-тырса (Stipa capillata L.), реже ковылок (Stipa lessingiana Trin. ex Rupr.), мелкодерновинные злаки (Festuca valesica Gaudin, Koeleria cristata (L.) Pers., Poa angustifolia L.). Естественная растительность представлена красноковыльными и разнотравно-морковниково-красноковыльными (Stipa zalesskii, Festuca valesiaca, Silaum silaus (L.) Schinz ex Thell.) сообществами с участием Bromopsis inermis (Leyss.) Holub и Poa angustifolia L. Для луговых степей характерно высокое разнообразие разнотравья (Filipendula vulgaris Moench., Artemisia sericea Web., Phlomoides tuberosa L., Salvia stepposa Shost., Lathyrus odoratus L., Silaum silaus и др. виды).

К возвышенным участкам равнин приурочены галофильные варианты степей с формированием типчаковых, ковыльно-типчаковых (Festuca valesica, Stipa lessingiana, S. sareptana A. Beck.) сообществ при участии ксерофитных кустарников (Caragana frutex (L.) C. Koch., Spiraea gypericifolia L.) и разнотравья (Pulsatilla patens (L.) Mill., Gallium boreale L.). К приподнятым понижениям рельефа приурочены разнотравно-ковыльно-типчаковые (Festuca valesiaca, Stipa pennata L., S. zalesskii, Plantago cornu$t i$ Gouan) с солонечником (Galatella tatarica (Less.) Novopork.) и полынью (Artemisia tenuisecta Nevski.) сообщества, развивающиеся на черноземах обыкновенных солонцеватых.

Целинная растительность этих степей повсеместно распахана, сохранились участки между полями пашни или у опушек леса.

\section{Злаково-разнотравные луга на лугово-черноземных и луговых почвах}

Луговой тип растительности представлен остепненными, настоящими и галофитными лугами на почвах полугидроморфного и гидроморфного режима увлажнения - лугово-черноземных почвах, солонцах лугово-степных и луговых почвах. Луга получили распространение по понижениям равнинных межколочных пространств, верхним частям озерных террас, развиваются в условиях дополнительного атмосферного и грунтового увлажнения.

По широким понижениям плакоров получили распространение остепненные злаково-разнотравные луга на лугово-черноземных почвах. В составе травостоя присутствуют ковыли (Stipa tir$s a$ Stev., S. pennata), узколистные и широколистные мезофильные злаки (Poa angustifolia, Elytrigia repens (L.) Nevski, Bromopsis inermis, Phleum pratense L.). В составе господствующего разнотравья встречается ряд мезофильных видов (Filipendula vulgaris, Sanguisorba officinalis L., Adonis parviflora Fisch. ex DC., Inula aspera Poir., Salvia stepposa, Eryngium planum L., Achillea asiatica Serg., Fragaria viridis 
(Duch.) Weston, Plantago urvillei Opiz., Vicia sepium L., Peucedanum morissonii Bess. ex Spreng., Bunium setaceum (Schrenk) H. Wolff).

Широкие понижения рельефа межколковых пространств отличаются развитием настоящих злаковых и разнотравно-злаковых лугов, развивающихся в условиях пресных или слабозасоленных грунтовых вод на луговых обыкновенных почвах. Для растительного покрова характерно доминирование злаков (Elytrigia repens, Bromopsis inermis, Phleum pretense, Calamagrostis epigeios, Festuca pratensis Huds., F. regeliana Pavl.) при участии полыней (Artemisia latifolia Ledeb., A. pontica L.). Из разнотравья получили распространение: Filipendula ulmaria (L.) Maxim, Anemone silvestris L., Convolvulus arvensis L., Lathyrus pratensis L., L. tuberosus L., Sanguisorba officinalis, Eryngium planum, Taracsacum officinale Wigg., Leucanthemum vulgare Lam., Vicia biennis L., V. sepium L., Achillea millefolium L., A. asiatica, Plantago urvillei, P. cornuti, Onobrychis arenaria (Kit.) DC.).

Приподнятые понижения характеризуются распространением галофитно-злаковых лугов на лугово-черноземных солонцеватых почвах и солонцах лугово-степных. В составе сообществ принимают участие злаки (Festuca valesiaca, Psathyrostachys juncea (Fisch.) Nevski, Leymus ramosus (Trin.) Tzvel., Stipa capillata, Phragmites australis (Cav.) Trin. ex Steud.), полынь (Artemisia nitrosa Web.), из разнотравья присутствуют Limonium gmelinii (Willd.) O. Kuntze, Plantago urvillei, Leucanthemum vulgare, Centaurea adpressa Ledeb., Astragalus danicus Retz., Scabiosa ochroleuca L., Achillea asiatica, Euphorbia falcata L.

При засолении почв в условиях близко расположенных минерализованных грунтовых вод формируются галофитные луга на луговых засоленных почвах. Преобладают разнотравно-злаковые (Elytrigia repens, Bromopsis inermis, Calamagrostis epigeios, C. pseudophragmites (Hall. fil.) Koel., Festuca pratensis, F. regeliana, Phragmites australis, Glyzzirisa uralensis Fisch., Sanguisorba officinalis L., Filipendula ulmaria, Onobrychis tanaitica Spreng., Achillea millefolium, Plantago urvillei, P. cornuti Gouan) и разнотравно-бескильнецевые (Puccinellia hauptiana V. Krecz, Juncus gerardii Loisel., Halimione verrucifera (Bieb.) Aell., Salicornia europaea L.) сообщества.

\section{Травяные болота}

Травяные болота формируются в депрессиях рельефа (центральные части западин, плоскодонные понижения и окраины пересыхающих озер) в условиях избыточного грунтового и поверхностного увлажнения на лугово-болотных и болотных почвах с доминированием крупных длиннокорневищных злаков, по типу водного питания относящихся к гидро- и гигрофитам. Преобладающее распространение получили гидрофитно-злаковые (Phragmites australis, Typha angustifolia L., Elytrigia repens, Calamagrostis epigeios, C. pseudophragmites, Filipendula ulmaria, Juncus gerardii, Butomus umbelatus L., Gentiana pneumonanthe L.), местами с ивой (Salix rosmarinifolia L.) травяные болота. Гидрофитно-злаково-осоковые (Phragmites australis, Carex pseudocyperus L., C. riparia Curt., Eleocharis uniglumis (Link) Schult., Cyperus glomeratus L., Juncus gerardii, Acorus calamus L.) сообщества с участием мхов формируются по западинам при процессах поверхностного заболачивания. Они нередко кочковаты из-за обилия осоки. По окраинам озерных впадин и пересыхающих озер развиты прибрежные заросли тростника, рогоза (Phragmites australis, Typha angustifolia).

В водоемах присутствует свободно плавающая и погруженная растительность. Распространение получили водокрас лягушечный (Hydroharis morsus-ranae L.), рдест сплюснутый и курчавый (Potamogeton compressus L., P. crispus L.), уруть мутовчатая (Myriophyllum verticillatum L.), роголистник полупогруженный (Ceratophyllum submersum L.). В солоноватых водах развиваются харовые водоросли, зостеры (Zostera sp.).

\section{Мелколиственные леса и колки на серых лесных почвах и солодях лесных}

Леса, разбросанные небольшими участками, приурочены к замкнутым понижениям, состоят из мелколиственных пород, развиваются на серых лесных осолоделых почвах и солодях лесных. Лесообразующими породами служат береза бородавчатая (Betula pendula Roht.), береза пушистая (Betula pubescens Ehrh.) и осина (Populus tremula L.). Для колков характерен подлесок, состоящий из поросли березы и осины. Ближе к центру встречаются древесные и кустарниковые виды ивы (Salix triandra L., 
S. caprea L., S. rosmarinifolia L.). В кустарниковом ярусе встречаются виды шиповника (Rosa acicularis Lindl., R. pimpinellifolia L.), спиреи (Spiraea crenata L., S. hypericifolia), вишня степная (Cerasus fruticosa Pall.). В травяном ярусе из злаков обычны злаки: Elytrigia repens, Festuca pratensis, Calamagrostis epigeios, Brachypodium pinnatum (L.) Beauv., из разнотравья получили распространение Artemisia latifolia, A. pontica, Salvia stepposa, Plantago urvillei, Achillea millefolium, Fragaria viridis, Rubus saxatilis L.

По глубоким и широким понижениям развиваются заболоченные лесные колки, центральная часть которых занята осоковыми (Carex pseudocyperus, C. riparia) болотами с зарослями ивы (Salix triandra, S. caprea, S. rosmarinifolia) и другими влаголюбивыми растениями. Встречаются плоскодонные понижения, дно которых покрыто осоковыми кочками, иногда с подушками мхов.

На территории обследования выделяются также местообитания на сильно засоленных почвах солонцах и солончаках, на которых развивается галофитная растительность. На солонцах корковых присутствует кермек Гмелина, лебеда бородавчатая, бескильница длинночешуйная, подорожник приморский (Limonium gmelinii, Halimione verrucifera (Bieb.) Aell., Puccinellia dolicholepis, Plantago salsa Pall.) и другие виды. На мокрых солончаках распространены заросли солероса (Salicornia europea).

\section{Растительность антропогенно нарушенных земель}

Значительные площади межлесных пространств, занимаемые черноземами обыкновенными и частично лугово-черноземными почвами, распаханы, использовались под посевы пшеницы, рапса, льна. В настоящее время они относятся к категории залежных земель, где были выделены сильно нарушенные сорные производные сообщества разных стадий восстановления. По доминантному составу растительных сообществ получили распространение три стадии развития залежей: бурьянистая сорнотравная, восстанавливающаяся длительно-производная и восстанавливающаяся по зональному типу с низким участием сорнотравья (Пермитина, 2018).

Для первой стадии типично преобладание сорнотравья (Lactuca tatarica (L.) C. A. Mey, Sonchus arvensis L.) при заметной роли культурных растений (Triticum durum Desf., T. aestivum L., Brassica napus L.). Группировки мозаичные, слабо сформированные, неустойчивые. Для второй стадии характерно наряду с сорнотравьем (Melilotus officinalis (L.) Pall., M. albus Medic., Atriplex tatarica, Convolvulus arvensis, Lapulla squarrosa (Retz.) Dumort., Euphorbia falcata) поселение в сообществах полыни (Artemisia vulgaris L., A. absinthium L.) при некотором участии Elytrigia repens, Poa angustifolia. Проективное покрытие составляет 45-50 \%. Видовое разнообразие представлено 10-15 наименованиями. На стадии восстановления типично формирование устойчивых разнотравно-злаковых (Elytrigia repens, Poa angustifolia, Leucanthemum vulgare, Achillea asiatica, Asparagus officinalis L., Rumex acetosa L., Eryngium planum, Silaum silaus) сообществ с незначительным участием сорнотравья. Проективное покрытие достигает 75-85\%. Видовое разнообразие представлено 20-25 наименованиями.

Антропогенно преобразованная растительность с преобладанием сорнотравных сообществ является источником засорения пастбищных земель. Наибольшее распространение получило засорение разнотравно-злаковых и злаково-разнотравных лугов латуком татарским (Lactuca tatarica), осотом полевым (Sonchus arvensis), донником лекарственным и белым (Melilotus officinalis, M. albus), липучкой растопыренной (Lapulla squarrosa), вьюнком полевым (Convolvulus arvensis), полынью обыкновенной (Artemisia vulgaris) и другими видами.

Проведенные исследования в лесостепной зоне Северного Казахстана показали высокое разнообразие растительных сообществ, относящихся к определенному типу: степному, луговому, болотному, лесному, что обусловлено рельефом местности, условиями увлажнения и типом почв.

Степной тип характеризуется преобладанием злаковых с разнотравьем сообществ, занимающих повышенные позиции волнистой равнины с распространением черноземов обыкновенных. Основу растительных сообществ составляют дерновинные злаки. Луговая растительность представлена богаторазнотравно-злаковыми и злаковыми сообществами. Травяные болота характеризуются развитием гидрофитных злаков и осок. Леса состоят из мелколиственных пород, кустарникового и травянистого яруса.

На участках распространения залежных земель формируется сорная растительность разной стадии восстановления. Прилегающие к ним пастбищные земли обычно засорены. Местами в них отмечается смена доминантного состава сообществ. 


\section{ЛИТЕРАТУРА}

Лавренко Е. М., Карамышева З. В., Никулина Р. И. Степи Евразии. - Л.: Наука, 1991. - 146 с.

Пачикина Л. И., Рубинштейн М. И. Почвы Кокчетавской области. // Почвы Казахской ССР. - Алма-Ата: АН КазССР, 1960. - Вып. 2. - 136 с.

Пермитина В. Н. Восстановление растительности залежных земель Северного Казахстана. // Проблемы ботаники Южной Сибири и Монголии: Сб. науч. ст. по материалам XIII междунар. науч.-практ. конф. (24-27 мая 2018 г., Барнаул). - Барнаул: Концепт, 2018. - С. 113-116.

Природное районирование Северного Казахстана (Кустанайская, Северо-Казахстанская, Кокчетавская, Акмолинская, Павлодарская области). - М.-Л.: АН СССР, 1960. - 468 с.

Природные условия и естественные ресурсы СССР. Казахстан. - М.: Наука, 1969. - 482 с.

Федорин Ю. В. Почвы Северо-Казахстанской области. // Почвы Казахской ССР. - Алма-Ата: АН КазССР, 1960. - Вып. 1. - 174 с. 